\title{
ABNORMAL MICROVASCULATURE IN DIABETIC NEUROPATHY
}

\author{
J. D. WARD \\ Sheffield
}

\begin{abstract}
SUMMARY
Microvascular abnormalities are prominent in the retina and kidney in diabetic subjects with the specific complications of the disease. It would not therefore be surprising to find similar changes in nerve, the other tissue prominently damaged in diabetes. A variety of biochemical abnormalities have been postulated as a cause of nerve damage but so far none has been reversed with any benefit to patients. It is now very clear that major structural and functional changes in the microvasculature occur in diabetic neuropathy and are probably involved in resulting nerve damage. Endothelial thickening of the endothelial basement membrane occurs, as does luminal occlusion caused by endothelial cell proliferation; human sural nerve is hypoxic; sural nerve epineurial arterioles are attenuated and involved in arteriovenous shunting associated with gross distension and tortuosity of veins; flow of fluorescein is impaired in neuropathic nerves and nerve conduction increment on exercise is impaired in neuropathy. Therapeutic intervention should now be directed at these gross abnormalities.
\end{abstract}

Although the aetiology and pathogenesis of human diabetic neuropathy remains unclear, microvascular/hypoxic and metabolic mechanisms have been postulated. The case for microvascular disease in diabetic neuropathy is strong. Fibre loss in human sural nerve is multifocal, suggesting ischaemia. The degree of endoneurial vessel disease has been related to the severity of neuropathy. People with chronic obstructive airways disease develop so-called hypoxic neuropathy in which similar microvascular changes occur as in diabetic neuropathy. In rats with experimental diabetic neuropathy nerve blood flow is reduced and oxygen supplementation has improved deterioration in nerve conduction velocity. Similarly, in human diabetic neuropathy there is impaired nerve blood flow, epineurial arteriovenous shunting and a reduction in sural nerve oxygen tension. The stage during the development of nerve damage at which these changes occur is yet to be determined.

Correspondence to: Professor J. D. Ward, MD, FRCP, Royal Hallamshire Hospital, Glossop Road, Sheffield S10 2JF, UK.
Diabetic polyneuropathy leads to considerable morbidity and mortality. ${ }^{1}$ Unpleasant sensory syndromes afflict approximately $10 \%$ of diabetic people and foot ulceration and infection result in many hospital admissions. ${ }^{2}$ In the United States neuropathy takes its place in the estimated 35000 amputations that occur annually. ${ }^{3}$ The incidence of diabetic neuropathy varies depending on diagnostic criteria. ${ }^{4}$ Despite the common clinical development of neuropathy the exact aetiology remains obscure. Undoubtedly poor glycaemic control plays a major part in nerve damage, ${ }^{5,6}$ but sorbitol accumulation in nerve coupled with myo-inositol depletion and a reduction in sodium-potassium-ATPase have all been postulated from work in animals. Non-enzymatic glycosylation of proteins, defective protein synthesis and abnormalities of axonal flow are also postulated as possible mechanisms. Of course it is possible that metabolic pathways have some effect on nerve vasculature. ${ }^{7,8}$

\section{MICROSCOPIC ABNORMALITIES OF NERVE BLOOD VESSELS IN DIABETIC NEUROPATHY}

In recent years there has been a revival of the case for microvascular disease in diabetic neuropathy from both human and animal studies. The idea that diabetic neuropathy might be due to vascular disease has its roots in early studies by Pryce ${ }^{9}$ and later work by Woltman and Wilder. ${ }^{10}$ They attributed neuropathy to arteriosclerosis of vasa nervorum. However, some of the 'infarcts' described by Woltman and Wilder have the appearances of Renaut's bodies which are found in normal nerve. ${ }^{11,12}$

Three decades later, Fagerberg drew attention to small vessel disease with thickening and hyalinisation of intraneural vessel wall by a material staining PAS positive, together with a reduction in vessel calibre, in diabetic neuropathy. ${ }^{13}$ These changes were later found to be due to reduplication of capillary basal lamina ${ }^{14}$ which in turn may be due to episodes of increased endothelial cell turnover; although found in other neuropathies, ${ }^{15-17}$ the phenomenon is commoner in diabetes. ${ }^{14}$

Several studies have since confirmed the presence of 
increased basement membrane thickness in endoneurial capillaries in chronic diabetic neuropathy. ${ }^{7,17-19}$ In a study by Malik et $a l^{7}$ endoneurial capillary basement membrane, endothelial cell and total diffusion barrier were significantly increased in diabetic neuropathy. These changes were found to be more severe in nerve capillaries compared with muscle or skin capillaries. Furthermore, the degree of endoneurial vessel disease has been related to the severity of both nerve fibre pathology and clinical neuropathy. ${ }^{7}$ This relationship has been reported by other studies. $^{13,18,19}$

Endothelial cell hyperplasia has been found in endoneurial capillaries in diabetic neuropathy, ${ }^{20,21}$ in some cases leading to complete occlusion of small vessels. ${ }^{21}$ However, endothelial cell hyperplasia has also been demonstrated in patients with type I hereditary motor and sensory neuropathy. ${ }^{16}$ In a study involving sural nerve biopsies from diabetic patients with progressive, mainly motor neuropathy, with good glycaemic control, Timperley et al. ${ }^{22}$ described plugging of small vessels by degenerate cellular material and electron-dense protein which was partly composed of fibrin. Endoneurial capillary closure has also been shown in patients with diabetic neuropathy, ${ }^{23}$ but this has not been confirmed by other studies. ${ }^{16,24}$

The diffuse symmetrical nature of many clinical syndromes of diabetic neuropathy has led to the postulate that the aetiology must be a diffuse metabolic abnormality. However, Dyck et al. $^{25}$ in a post-mortem study of transverse sections of nerve roots in the lower limb found that the spatial distribution of fibre loss in diabetic neuropathy suggested ischaemia. The same group in teasing nerve fibres of sural nerve demonstrated that fibre loss in diabetic neuropathy is primary and multifocal, again suggesting ischaemia. ${ }^{26}$

\section{EXPERIMENTAL ISCHAEMIC NEUROPATHY}

The blood supply of the peripheral nerve is abundant. In a series of experiments performed on the dog sciatic nerve, Roberts $^{27}$ found that when the blood supply of a nerve was obliterated by ligating a single nutrient artery or nutrient arteries of a small segment, only partial or patchy ischaemia usually occurred because collateral anastomoses through the longitudinal vessels in the nerve could maintain adequate nutrition. This has since been confirmed by other studies. ${ }^{28,29}$ To occlude endoneurial vessels selectively, Nukada and Dyck ${ }^{29,30}$ injected microspheres into arteries supplying the sciatic nerve; they reported that many microvessels had to be occluded before fibre degeneration occurred. Benstead et al..$^{31}$ ligated major pelvic arteries of rats in order to study the acute morphological effect of ischaemia on ultrastructural features of endoneurial microvessels. They observed that in ischaemic nerves there was an increase in endothelial cells, pericytes and basement membrane. The endothelial cells appeared swollen with abundant mitochondria. This study suggests that ischaemia has a direct effect on the microvessel wall in addition to its well-established effect on nerve fibres. ${ }^{27,29}$

Further animal studies strengthen the case for microvascular mechanisms in pathogenesis. Tuck et al. demonstrated reduced nerve blood flow and oxygen tension in rats with experimental diabetic neuropathy and Low et al. showed that supplementation with oxygen or the use of hyperbaric oxygen improved the deterioration in nerve conduction velocity. ${ }^{32,33}$ In a hypoxic environment normal rats developed electrophysiological ${ }^{34}$ and morphological ${ }^{35}$ abnormalities similar to those seen in experimental diabetes, while oxygen supplementation was able partially to prevent conduction slowing. ${ }^{36}$

\section{PATTERNS OF BLOOD FLOW AND OXYGEN TENSION IN HUMAN DIABETIC NEUROPATHY}

The role of epineurial nutrient arterioles is obviously important, but has not been investigated in as much detail as that of endoneurial vessels. Korthals et $a .^{37}$ measured the epineurial arteriolar wall components in sural nerves of healthy controls and of diabetic subjects most of whom had neuropathy. Intimal area and numbers of intimal nuclei were significantly greater in diabetic subjects compared with controls. The authors concluded that the increased intima, and the possible resulting decrease in nerve perfusion, may contribute to the development of diabetic neuropathy, although they found no direct relationship between the increase in intima and severity of nerve fibre degeneration.

\section{BLOOD FLOW AND OXYGEN TENSION IN THE DIABETIC PERIPHERAL NERVE}

In human diabetic neuropathy although there is a reduction in sural nerve oxygen tension there is an elevation in oxygen tension in the foot veins due to arteriovenous shunting. ${ }^{38}$ From other work it is well established that there is arteriovenous shunting in the diabetic neuropathic foot with large distended veins, ${ }^{28,29}$ and it seems that similar shunting is taking place in nerve itself. A novel in vivo technique has been developed for visualisation at high magnification of epineurial vessels in exposed sural nerves, ${ }^{27}$ and following photography a technique of nerve fluorescein angiography has also been applied which allows the study of nerve blood flow in exposed sural nerve. ${ }^{38}$ After intravenous administration of fluorescein its appearance in the nerve was monitored using a closed circuit television attached to an operating microscope. The fluroscein appearance time and intensity of fluorescence were quantified using computer analysis of video digitised images. The intensity of nerve fluorescence was markedly reduced in subjects with diabetic neuropathy compared with non-neuropathic diabetic and normal controls, suggesting impaired nerve blood flow in human diabetic neuropathy.

Haemorrheological abnormalities that have been described in diabetes may contribute to impaired blood flow brought about by microvascular disease. ${ }^{39}$ Fibrin 
deposition and platelet clamping have been observed in endoneurial vessels in diabetic neuropathy. ${ }^{20.40}$ The abnormalities of platelet function, ${ }^{40}$ the increased blood and plasma viscosity, ${ }^{41-43}$ the reduced red cell deformability, ${ }^{44,45}$ and the increased erythrocyte aggregability and adhesiveness, ${ }^{46,47}$ may lead to a reduction in capillary erythrocyte velocity. ${ }^{48,49}$ Episodes of sludging and stasis that may consequently develop, may, if severe, lead to local hypoxia.

The exact stage at which the structural and functional abnormalities of the microvasculature occur is yet to be established. However, gross microvascular abnormalities have been described in 5 patients developing acute painful neuropathy soon after the institution of blood glucose control by the use of insulin. In vivo studies as described above revealed leakage of fluorescein and gross abnormalities of the epineurial vessels with obvious arteriovenous shunting and leashes of small proliferating vessels identical to those described in proliferative diabetic retinopathy. ${ }^{50}$

\section{A POTENTIAL MARKER OF IMPAIRED NERVE BLOOD FLOW}

Despite the availability of neurophysiological and quantitative sensory testing, we do not have a marker of early diabetic neuropathy or of impaired peripheral nerve blood flow (if this is indeed an important factor). A non-invasive test has been developed which may identify those diabetic subjects who will eventually develop neuropathy - clearly a prerequisite for early intervention. ${ }^{51}$ The test involves measuring sural sensory conduction velocity and subcutaneous temperature near the sural nerve before and after exercise on a treadmill to $80 \%$ maximal heart rate. Sural sensory conduction velocity increased significantly after exercise in normal subjects (mean increase $5.07 \mathrm{~m} / \mathrm{s}$ ) and non-neuropathic diabetic subjects (mean increase $3.99 \mathrm{~m} / \mathrm{s}$ ) but not in neuropathic subjects (mean increase $0.99 \mathrm{~m} / \mathrm{s}$ ). We have also found diabetic subjects with a Dyck's neuropathy score ${ }^{52}$ of 0 (i.e. no neuropathy) who are unable to increase their nerve conduction velocity after exercise. We speculate that these may be the diabetics who go on to develop clinical neuropathy. This will have to be confirmed by further studies, but if it proves to be the case, then this simple non-invasive test, which is within the means of most hospitals in the United Kingdom, may be regarded as an early marker of impaired nerve blood flow.

\section{REFERENCES}

1. Ward JD, Goto Y, editors. Diabetic neuropathy. Chichester: Wiley, 1990.

2. Ward JD. The diabetic leg. Diabetologia 1982;22:141-7.

3. Levin ME, O'Neal LW. Preface. In: The diabetic foot. St. Louis, Mosby, 1983.

4. Thomas PK, Eliasson. Diabetic neuropathy. In: Dyck PJ, Thomas PK, Lambert EH, Bunge E, editors. Peripheral neuropathy, vol. 2. 2nd ed. Philadelphia: Saunders, 1984: 1773-1810.

5. Bondy PK, Felig P. Relation of diabetic control to development of vascular complications. Med Clin North Am 1971; 55:889-97.
6. Ward JD, Barnes CG, Fisher DJ, Jessop JD, Baker RWR. Improvement in nerve conduction following treatment in newly diagnosed diabetics. Lancet 1971;1:428-30.

7. Malik RA, Newrick PG, Sharma AK, Jennings A, Ah-See AK, Mayhew TM, Jakubowski J, Boulton AJM, Ward JD. Microangiopathy in human diabetic neuropathy: relationship between capillary abnormalities and the severity of neuropathy. Diabetologia 1986;32:92-102.

8. Dyck PJ. Hypoxic neuropathy: does hypoxia play a role in diabetic neuropathy? Neurology 1989;39:111-8.

9. Pryce TD. On diabetic neuritis with a clinical and pathological description of three cases of diabetic pseudo-tabes. Brain 1983;16:416-24.

10. Woltman HW, Wilder RM. Diabetes mellitus: pathological changes in the spinal cord and peripheral nerves. Arch Intern Med 1929;44:576-603.

11. Sugimura K, Dyck PJ. Multifocal fibre loss in proximal sciatic nerve in symmetrical distal diabetic neuropathy. J Neururol Sci 1982;53:501-9.

12. Renaut J. Recherches sur quelques points particuliers de l'histologie des nerfs. I. La gaine lamelleuse et le sýstème hyalin intervaginal. Arch Physiol Norm Pathol 1881;8: 161-90.

13. Fagerberg SE. Diabetic neuropathy: a clinical and histological study on the significance of vascular affections. Acta Med Scand 1959;164(Suppl 345):5-81.

14. Bischoff A. Morphology of diabetic neuropathy. Horm Metab Res (Suppl) 1980;9:18-28.

15. Vital C, Le Blanc M, Vallat JM, Coquet M, Vallat M, Roques JC. Etude ultrastructurale du nerf périphérique chez 16 diabétiques sans neuropathie clinique. Acta Neuropathol (Berl) 1974; 30:63-72.

16. Bradley J, Thomas PK, King RH, Llewelyn JG, Muddle JR, Watkins PJ. Morphometry of endoneurial capillaries in diabetic sensory and autonomic neuropathy. Diabetologia 1990;33:611-8.

17. Behse F, Buchthal F, Carlsen F. Nerve biopsy and nerve conduction studies in diabetic neuropathy. J Neurol Neurosurg Psychiatry 1977;40:1072-82.

18. Yasuda H, Dyck PJ. Abnormalities of endoneurial microvessels and sural nerve pathology in diabetic neuropathy. Neurology 1987;37:20-8.

19. Britland ST, Young RJ, Sharma AK, Clarke BF. Relationship of endoneurial capillary abnormalities to type and severity of diabetic polyneuropathy. Diabetes 1990; 39:909-13.

20. Timperley WR, Ward JD, Preston FE, Duckworth T, O'Malley BC. Clinical and histological studies in diabetic neuropathy. Diabetologia 1976;12:237-43.

21. Williams E, Timperley WR, Ward JD, Duckworth T. Electronmicroscopical studies of vessels in diabetic peripheral neuropathy. J Clin Pathol 1980;33:462-70.

22. Timperley WR, Boulton AJM, Davies Jones GAB, Jarrat JA, Ward JD. Small vessel disease in progressive diabetic neuropathy associated with good metabolic control. J Clin Pathol 1985;38:1030-8.

23. Dyck PJ, Hansen S, Karnes J, et al. Capillary number and percentage closed in human diabetic sural nerve. Proc Natl Acad Sci USA 1985;82:2513-7.

24. Powell HC, Rosoff J, Myers RR. Microangiopathy in human diabetic neuropathy. Acta Neuropathol (Berl) 1985;68: 295-305.

25. Dyck PJ, Karnes JL, O’Brien P, Okazaki H, Lias A, Engelstad J. The spatial distribution of fibre loss in diabetic polyneuropathy suggests ischaemia. Ann Neurol 1986;19: 440-9.

26. Dyck PJ, Lais A, Karnes JL, O’Brien P, Rizza R. Fibre loss is primary and multifocal in sural nerves in diabetic polyneuropathy. Ann Neurol 1986;19:425-39.

27. Roberts JT. The effect of occlusive arterial diseases of the extremities of the blood supply of nerves: experimental and 
clinical studies on the vasa nervorum. Am Heart J 1948;35: 369-92.

28. Korthals JK, Wisniewski HM. Peripheral ischaemia. I. Experimental model. J Neurol Sci 1975;24:65-76.

29. Nukada H, Dyck PJ. Acute ischaemia causes axonal stasis, swelling, attenuation, and secondary demyelination. Ann Neurol 1987;22:311-8.

30. Nukada H, Dyck PJ. Microsphere embolization of nerve capillaries and fibre degeneration. Am J Pathol 1984;115: 275-87.

31. Benstead TJ, Sangalang VE, Dyck PJ. Acute endothelial swelling is induced in endoneurial microvessels by ischaemia. J Neurol Sci 1990;99:37-49.

32. Low PA, Tuck RR, Dyck PJ, Schmelzer JD, Yao JK. Prevention of some electrophysiologic and biochemical abnormalities with oxygen supplementation in experimental diabetic neuropathy. Proc Natl Acad Sci USA 1984;81:6894-8.

33. Low PA, Schmelzer JD, Ward KK, Curran GL, Poduslo JF. Effect of hyperbaric oxygenation on normal and chronic streptozototocin diabetic peripheral nerves. Exp Neurol 1988;99:201-12.

34. Low PA, Schmelzer JD, Ward KK, Yao JK. Experimental chronic hypoxic neuropathy: relevance to diabetic neuropathy. Am J Physiol 1986;250:E94-9.

35. Benstead TJ, Dyck PJ, Low P. Chronic hypoxia induces selective maldevelopment of peripheral myelin in rat. J Neuropathol Exp Neurol 1988;47:599-608.

36. Low PA, Tuck RR, Takeuchi M. Nerve microenvironment in diabetic neuropathy. In: Dyck PJ, Thomas PK, Asbury AK, Winegrad AI, Porte D, editors. Diabetic neuropathy. Philadelphia: Saunders, 1987:266-78.

37. Korthals JK, Gieron MA, Dyck PJ. Intima of epineural arterioles is increased in diabetic polyneuropathy. Neurology 1988;38:1582-6.

38. Tesfaye S, Harris N, Jakubowski J, Mody C, Ward JD. Impaired blood flow and evidence of arteriovenous shunting in human diabetic nerve. Diabetes 1991;40 (Suppl 1):514A.

39. Greaves M, Preston FE. Haemostatic abnormalities in diabetes. In: Jarrett RJ, editor. Metabolic aspects of cardio- vascular disease, vol. 2, Diabetes and heart disease. Oxford: Elsevier, 1984:47-80.

40. O’Mally BC, Timperley WR, Ward JD, Porter NR, Preston FE. Platelet abnormalities in diabetic neuropathy. Lancet 1975;2:1274-6.

41. Barnes AJ, Locke P, Scudder PR, Dormandy TL, Dormandy JA, Slack J. Is hyperviscosity a treatable component of diabetic microcirculatory disease? Lancet 1977;2:789-91.

42. Baba Y, Kai M, Kamanda T, Setoyama S, Otsugi S. Higher levels of erythrocyte membrane microviscosity in diabetes. Diabetes 1979;28:1138-40.

43. McMillan DE. Further observations in serum viscosity change in diabetes mellitus. Metabolism 1982;31:274-8.

44. Schmid-Schonbein H, Volger E. Red-cell aggregation and red cell deformability in diabetes. Diabetes 1976;25 (Suppl 2):897-902.

45. McMillan DE, Utterback NG, La Puma J. Reduced erythrocyte deformability in diabetes. Diabetes 1978;27:895-901.

46. Satoh M, Imaizumi K, Bessho T, Shiga T. Increased erythrocyte aggregation in diabetes mellitus and its relationship to glycosylated haemoglobin and retinopathy. Diabetologia 1984;27:517-21.

47. Wautier J-L, Paton RC, Wautier MP, et al. Increased adhesion of erythrocytes to endothelial cells in diabetes mellitus and its relation to vascular complications. N Engl J Med 1981;305:237-42.

48. Bohlen HG. Tissue $\mathrm{PO}_{2}$ in the intestinal muscle layer of rats during chronic diabetes. Circ Res 1983;53:677-82.

49. Keisewetter H, Jung F, Korber N, et al. Microcirculation and hemorheology of children with type I diabetes. Klin Wochenschr 1986;64:962-8.

50. Tesfaye S, Mody C, Jakubowski JJ, Harris N, Ward JD. (Submitted for publication).

51. Tesfaye S, Harris N, Ward JD. Exercise induced conduction velocity increment: a marker of impaired nerve blood flow in diabetic neuropathy. Diabetologia 1992;35:155-9.

52. Dyck PJ. Detection, characterization, and staging of polyneuropathy. Muscle Nerve 1988;11:21-32. 